\title{
PERSENTASE KARKAS DAN GIBLET AYAM BROILER (GALLUS DOMESTICUS) YANG DIBERI EKSTRAK DAUN KELOR (MORINGA OLIFERA)
}

\section{PERCENTAGE OF CARCASS AND GIBLET OF BROILER CHICKEN (GALLUS DOMESTICUS) THAT GIVEN THE EXTRACT OF MORINGA (MORINGA OLIFERA) LEAF}

\author{
Etik $^{1 a}$, Anggraeni, dan E Dihansih \\ 1Programstudi Peternakan Fakultas Pertanian Universitas Djuanda Bogor, Jl. Tol Ciawi No. 1, Kotak Pos \\ 35 Ciawi, Bogor 16720. \\ ${ }^{a}$ Korespondensi: Etik, E-mail: etkelanas@gmail.com \\ (Diterima oleh Dewan Redaksi: xxxx) \\ (Dipublikasikan oleh Dewan Redaksi: 31 Oktober 2021)
}

\begin{abstract}
The study was conducted to examine the effect of giving Moringa leaf extract in drinking water to increase the percentage of carcass and giblets of broiler chickens. The research was conducted at the Chicken Farmer's Cage, Cibanteng, Dramaga, Bogor Regency, West Java. The livestock were used in this study were a broiler chicken of strain cobb aged of 30 days as much as 80 chickens. This study used a completely randomized design consisting of 4 treatments and 5 replications. The treatment in research were $\mathrm{R}_{0}$ (Water drink without giving Moringa leaf extract), $\mathrm{R}_{1}$ (water drink of $90 \%+10 \%$ of Moringa leaf extract), $\mathrm{R}_{2}$ (water drink of $80 \%+20 \%$ of Moringa leaf extract), and $\mathrm{R}_{3}$ (water drink of $70 \%+30 \%$ of MOringa leaf extract). The data obtained were analyzed using analysis of variance (ANOVA), when the data shown the results of the sinificanthly different $(\mathrm{P}<0.05)$ followed by the test of Duncan. The variables that were observed in the study were the slaughter waight, the ewight of carcass, percentage of carcass and percentage of giblet. Results of the study showed thah giving og Moringa leaf eztract up to $30 \%$ can be used to optimize the percentage of broiler chicken carcass aged 30 days.

Kata Kunci : laying hens, Moringa leaf extract, carcass, giblet.
\end{abstract}

\begin{abstract}
ABSTRAK
Penelitian dilakukan untuk menguji pengaruh pemberian ekstrak daun kelor dalam air minum terhadap peningkatan persentase karkas dan giblet ayam broiler. Penelitian dilaksanakan di Kandang Peternak Ayam Cibanteng, Dramaga, Kabupaten Bogor, Jawa Barat. Ternak yang digunakan pada penelitian ini ayam broiler Strain cobb umur 30 hari sebanyak 80 ekor. Penelitian ini menggunakan rancangan acak lengkap (RAL) yang terdiri dari 4 perlakuan dan 5 ulangan. Perlakuan dalam penelitian ini R0 = Air minum tanpa pemberian ekstrak daun kelor, R1 = Air minum 90\% + 10\% ekstrak daun kelor, R2 = Air minum 80\% + 20\% ekstrak daun kelor, R3 = Air minum 70\% + 30\% ekstrak daun kelor. Data yang diperoleh dianalisis menggunakan Analisys of variance (ANOVA), bila data menunjukan hasil yang berbeda nyata $(\mathrm{P}<0,05)$ dilanjutkan dengan uji Duncan. Peubah yang diamati dalam penelitian ini adalah bobot potong, bobot karkas, persentasi karkas dan persentasi giblet. Hasil penelitian menunjukan pemberian ekstrak daun kelor sampai di 30\% dapat digunakan untuk mengoptimalkan persentase karkas ayam broiler umur 30 hari.
\end{abstract}

Kata Kunci : ayam petelur, ekstrak daun kelor, karkas, giblet.

Etik, Anggraeni, dan E Dihansih.2021. Persentase Karkas dan Giblet Ayam Broiler (Gallus Domesticus) Yang Diberi Ekstrak Daun Kelor (Moringa olifera). Jurnal Peternakan Nusantara 7(2): 107-116. 


\section{PENDAHULUAN}

Pemeliharaan domba di Indonesia pada Seiring dengan perkembangan waktu, pertambahan jumlah penduduk, peningkatan pendapatan dan kesadaran masyarakat akan arti pentingnya gizi bagi kesehatan tubuh, maka permintaan masyarakat akan arti pentingnya gizi bagi kesehatan tubuh, maka permintaan masyarakat akan kebutuhan pangan sumber protein hewani semakin meningkat.

Salah satu pangan sumber protein hewani yang digemari oleh masyarakat adalah daging ayam. Daging ayam yang dikonsumsi biasanya berasal dari daging ayam broiler dan daging ayam kampung. Namun, ketersedian akan ayam kampung masih terbatas dan harganya relatif mahal. Oleh sebab itu, ada alternatif lain yang digunakan untuk menggantikan daging ayam kampung yaitu daging ayam broiler.

Produksi daging ayam broiler di Indonesia berkembang dengan pesat. Pada peternakan komersil biasanya untuk pemeliharaan ayam ini menggunakan obat-obatan, antibiotik dan vitamin. Penggunaan antibiotik yang terus menerus dengan dosis kurang tepat akan menimbulkan resistensi. Selain itu bakteri yang ada dalam saluran pencernaan dapat ikut terbunuh akibat spektrum kerja antibiotik yang luas. Lebih lanjut residu yang tersisa pada produk bahan pangan asal ternak yang dikonsumsi juga dapat menimbulkan dampak negatif terhadap kesehatan masyarakat. Daun kelor (Moringa oleifera L) secara umum mengandung beberapa zat yaitu :

Hypotensive (Niacimicin, Pterygospermin) yang berfungsi sebagai anti kanker dan anti bacterial, Zat anti oksidan alami antara lain Sitosterol dan Glukopyranosidyang berfungsi menjaga struktur makro molekul dasar biologis dan menghambat oksidasi zat yang mudah teroksidasi serta menangkal radikal bebas oksigen reaktif jika berkaitan dengan penyakit, Kandungan karotenoid, selenium, flavonoid dan fenolik dapat memperbaiki kualitas daging dan produknya serta berfungsi sebagai suplemen protein yang mempunyai nilai gizi tinggi. Zat aktif dalam daun kelor mempunyai efek anti bakteri yang diharapkan mampu meningkatkan kinerja organ dalam dan mencegah kerusakan organ dalam terutama pancreas sehingga meningkatkan metabolisme dan penyerapan nutrisi (karbohidrat, lemak dan protein) dalam tubuh ternak untuk proses pertumbuhan yang menghasilkan keseimbangan antara karkas dan non karkas (Analisa 2007).

Efisiensi penggunaan larutan daun kelor dalam air minum belum memberikan informasi yang cukup mengenai sejauh mana pengaruh yang diberikan terhadap karakteristik karkas. Oleh karena itu, perlu adanya kajian lebih lanjut ditinjau dari persentase bobot karkas dan giblet. Berdasarkan uraian tersebut, maka permasalahan yang dapat diidentifikasi pada penelitian ini adalah daun kelor diketahui mengandung zat aktif anti oksidan dan anti bakteri yang mampu meningkatkan kinerja dan mencegah kerusakan organ dalam sehingga berpengaruh terhadap peningkatan metabolisme dan penyerapan nutrisi dalam tubuh ternak yang dapat memicu pertumbuhan, dalam hal ini pertumbuhan bobot badan ayam broiler yang terdiri atas peningkatan bobot karkas dan giblet di mana pada umumnya juga diikuti dengan proses deposisi lemak abdomen yang berkorelasi positif dengan total lemak karkas yang dianggap hasil ikutan yang menghamburkan energi dalam ransum yang menyebabkan penurunan kualitas dan bobot karkas yang dapat dikonsumsi. Penelitian ini bertujuan untuk menguji pengaruh pemberian ekstrak daun kelor dalam air minum terhadap peningkatan persentase karkas dan giblet ayam broiler.

\section{MATERI DAN METODE}

\section{Materi}

Penelitian dilaksanakan di desa Cibanteng, Dramaga, Kab Bogor. Penelitian dilaksanakan selama 30 hari pada bulan Februari - Maret 2019. Ayam yang digunakan adalah DOC (Day Old Chick) ayam broiler strain Cobb dengan berat badan homogen yaitu 37 gram. Ayam diperoleh dari PT Sierad Produce Tbk dengan syarat : sehat, mata cerah, tidak cacat, bergerak aktif, ekstrak daun kelor, pakan. Pakan yanag digunakan menggunakan pakan komplit dari UD. Golden Egg yang dalam bentuk butiran dan 
ekstrak daun kelor yang disusun sesuai perlakuan.

Kandang yang digunakan adalah kandang "open house" yang terbuat dari bambu dan triplek. Ukuran tiap petak kandang aklimatisasi adalah panjang $35 \mathrm{~cm}$, lebar $35 \mathrm{~cm}$, dan tinggi $60 \mathrm{~cm}$. Sedangkan ukuran kandang pada saat perlakuan adalah panjang $70 \mathrm{~cm}$, lebar $70 \mathrm{~cm}$, dan tinggi $60 \mathrm{~cm}$. Susunan kandang sejajar sebanyak 16 petak, pada setiap petak terdapat 4 ekor ayam broiler strain Cobb. Tempat ransum dan minum terbuat dari plastik dan masingmasing petak terdapat 1 tempat ransum dan 1 tempat minum volume 1 Liter. Peralatan lain yang digunakan dalam penelitian ini yaitu timbangan, peralatan kebersihan kandang, keranjang dan peralatan yang dibutuhkan lainnya. dilengkapi tempat pakan dan minum, timbangan digital. Alat untuk membuat larutan daun kelor antara lain pisau, panci, kompor, gelas ukur, timbangan digital kapasitas $1000 \mathrm{~g}$ dengan ketelitian $1 \mathrm{~g}$, dan alat dokumentasi.

\section{Perlakuan}

Perlakuan penelitian adalah sebagai berikut: $\mathrm{R} 0=$ Air minum tanpa pemberian ekstrak daun kelor. R1= Air minum 90\% dengan $10 \%$ ekstrak daun kelor. R2 $=$ Air minum $80 \%$ dengan $20 \%$ ekstrak daun kelor. $\mathrm{R} 3=$ Air minum $70 \%$ dengan 30\% ektrak daun kelor.

\section{Rancangan Percobaan}

Metode penelitian ini menggunakan rancangan percobaan rancangan acak lengkap (RAL) dengan 4 perlakuan dengan 5 ulangan (masingmasing 4 ekor) sehingga digunakan 80 ekor ayam broiler. Perlakuan adalah memberikan ekstrak daun kelor. Model matematika yang digunakan untuk rancangan acak lengkap adalah :

Yij $=\mu+\mathrm{Ti}+€ \mathrm{ij}$

Keterangan:

$\mathrm{i} \quad=1,2,3 \ldots \ldots . \mathrm{i}$ adalah perlakuan

$\mathrm{j} \quad=1,2,3 \ldots \ldots . \mathrm{j}$ adalah ulangan

Yij = variabel respon dari perlakuan ke-i dan ulangan ke-j

$\mu \quad=$ rataan umum atau nilai tengah umum

$\mathrm{Ti}=$ pengaruh perlakuan ke- $\mathrm{i}$

$€ \mathrm{ij} \quad=$ galat perlakuan ke-i dan ke-j

\section{Peubah yang Diamati}

Peubah yang diamati pada penelitian ini meliputi:

\section{Bobot Potong (g).}

Pengukuran bobot hidup akhir dilakukan pada umur 30 hari sampel sebanyak 2 ekor dari setiap unit petak kandang percobaan diambil secara acak, kemudian dilakukan penimbangan bobot hidup satu persatu sebagai bobot hidup akhir sebelum dipotong dengan menggunakan satuan gram.

\section{Bobot Karkas (g).}

Karkas dapat diidentifikasikan dengan cara melakukan pemotongan sebelumnya. Pemotongan ayam broiler dilakukan dengan cara menyembelih bagian atas leher dekat kepala dengan memotong vena jugularis, arteri carotis, esophagus dan trachea.Karkas didefinisikan sebagai bagian tubuh dari ternak unggas yang disembelih, dicabut bulunya, dikeluarkan isi rongga perut dan dibersihkan tanpa bagian leher, kepala dan kaki. Bobot karkas utuh adalah berat karkas secara keseluruhan yang terdiri atas bagian dada, paha, punggung dan sayap.

\section{Persentase Karkas (\%)}

Dapat diukur dengan membandingkan berat ayam broiler tanpa bulu, darah, kepala, leher, kaki dan organ dalam dalam satuan gram dengan bobot hidup (gram) kemudian dikalikan 100 .

$$
\begin{aligned}
& \text { Persentase karkas (\%) } \\
& =\frac{\text { berat hidup }- \text { berat non karkas }(g)}{\text { berat hidup }} X 100 \%
\end{aligned}
$$

\section{Persentase Giblet (\%)}

Pengukuran giblet dilakukan dengan menimbang bagian-bagian yang telah dipisahkan dari karkas setelah pemotongan, terdiri atas: rampela (gizzard), hati,dan jantung dengan menggunakan satuan gram. Cara mendapatkan bagian-bagian giblet adalah masing-masing dilepas dari organ lain. Persentase giblet yang akan diambil datanya yaitu dengan perbandingan berat giblet dengan bobot potong dan dinyatakan dalam persen (\%).

$$
\begin{aligned}
& \text { Persentase bagian giblet (\%) } \\
& =\frac{\text { bobot bagian giblet }(g)}{\text { bobot potong }(g)} \times 100 \%
\end{aligned}
$$




\section{Analisis Data}

Data yang diperoleh dianalisis dengan sidik ragam (ANOVA) dan jika perlakuan berpengaruh nyata terhadap peubah yang diamati maka analisis dilanjutkan dengan uji lanjut jarak ganda Duncan dengan menggunakan bantuan piranti program SPSS 16.

\section{Prosedur Pelaksanaan}

Kandang dibersihkan dan dicuci dengan desinfektan berspektrum luas mengandung Glutaraldehide 30\%, Benzylmethylamonium Chlorida $20 \%$ dan Isopropanol 10\% (dosis 2.5$10 \mathrm{ml} /$ liter air). Setelah kandang bersih, maka kandang dan litternya ditaburi kapur/gamping.

Tempat pakan, tempat minum (gallon minum $500 \mathrm{ml}$ ), disemprot menggunakan Desinfektan mengandung Ammonium Quat yang setiap ml mengandung Benzalkonium Chloride 20\%. Desinfektan tersebut memberikan indikasi membunuh virus, bakteri dan jamur.

Ternak yang digunakan adalah 80 ekor ayam broiler. Ayam harus sehat dengan ciri-ciri: tubuh tidak cacat, kaki kiri dan kanan tidak bengkok, paruh simetris dan kondisinya normal, ukuran tubuh normal (tidak terlalu besar maupun terlalu kecil, dan berat badannya proporsional), memiliki bulu tubuh yang kering, bulu tubuh merata, tidak lengket atau gembel, lincah, sehat, mata cerah dan bercahaya, serta kalau berdiri terlihat kokoh.

Ayam ditempatkan pada koloni/petak kandang perlakuan secara acak sesuai rancangan acak lengkap. Penempatan ayam broiler di acak berdasarkan hasil pengacakan diikuti dengan masing-masing perlakuannya. Masing-masing koloni/ petak kandang di isi 4 ekor ayam broiler dengan umur dan berat rataan yang seragam. Ayam broiler dipelihara dalam kandang selama penelitian. Sebelum memasuki tahap perlakuan, ayam broiler diadaptasikan dengan lingkungan penelitian. Adaptasi dilakukan selama 3 hari dengan perlakuan yang akan diujikan.

Daun kelor yang digunakan adalah daun kelor (Moringa oleifera Lam) yang tidak terlalu tua dan tidak terlalu muda (masa panen 45 hari). Daun kelor yang sudah dipetik kemudian dicuci dengan menggunakan air bersih. Daun kelor ditimbang sebanyak $1 \mathrm{~kg}$ dan diblender dalam 1 liter air. Kemudian dimaserasi panas dengan cara direbus selama 30 menit dalam suhu $50^{\circ} \mathrm{C}$ (Parwata et al 2016). Setelah itu ekstrak daun kelor didinginkan dan disaring serta dimasukkan ke dalam botol untuk digunakan pada perlakuan penelitian. Sebelum dilakukan perlakuan, ayam diaklimatisasi dengan air minum yang sedikit demi sedikit dicampur dengan ekstrak daun kelor untuk penyesuaian sistem pencernaan ayam.

Pemberian ransum dan air minum diberikan secara adlibitum. Pemberian pagi dimulai pukul 07.00 WIB. Air minum yang akan digunakan pada penelitian ini adalah air minum yang diberi perlakuan larutan daun kelor sesuai perlakuan.

Pada akhir penelitian, setelah ayam broiler mencapai 30 hari, ditimbang untuk mendapatkan bobot hidup. Sebelum dilakukan penyembelihan, ayam broiler tidak diberi ransum atau dipuasakan selama 3-4 jam kemudian di timbang kembali untuk memperoleh bobot potong (Genchev dan Mihaylova 2008). Selanjutnya dikatakan Soeparno (1992) bahwa maksud unggas dipuasakan agar diperoleh bobot tubuh kosong dan mempermudah proses pemotongan. Sebelum dilakukan pemotongan, ayam broiler ditimbang dan dari masing-masing ulangan diambil sampel secara acak 2 ekor dari masingmasing perlakuan. keluar secara sempurna. Langkah selanjutnya ditimbang kembali.

Pengambilan data karkas dan giblet diambil sampling 2 ekor dari masing-masing perlakuan; yaitu dari 20 petak kandang di ambil 2 ekor ayam broiler secara acak sederhana untuk di potong. Jumlah sampel sebanyak 40 sampel. Sedangkan untuk mendapatkan berat bagian giblet (rampela, hati dan jantung) sebelum melakukan pemotongan bagian karkas, pengeluaran atau pemisahan isi jeroan dan bagian giblet dipisahkan dan di timbang. Persentase giblet yang akan diambil datanya yaitu perbandingan rampela ,hati dan jantung dengan bobot potong yang dinyatakan dalam persen. 


\section{HASIL DAN PEMBAHASAN}

\section{Bobot Potong}

Bobot potong merupakan hasil identifikasi terhadap produksi yang paling mudah diketahui. Bobot potong merupakan gambaran pertumbuhan bagi ayam pedaging, yang digunakan untuk menilai keberhasilan suatu usaha peternakan. Bobot potong ayam broiler yang diberi perlakuan mempunyai berat yang Tabel 1 Rataan Bobot Potong beserta Rataan Bobot Relatif (\%) Ayam Broiler Umur 30 hari

\begin{tabular}{cllll}
\hline PRLKN & R0 & R1 & R2 & R3 \\
\hline 1 & $872.5 \pm 53,03$ & $1150,0 \pm 148,49$ & $1087,5 \pm 53,03$ & $1267,5 \pm 286,38$ \\
2 & $982,5 \pm 88$ & $1130 \pm 92$ & $980,0 \pm 35$ & $1012,5 \pm 103$ \\
3 & $812.5 \pm 3,54$ & $1190,0 \pm 106,06$ & $1145,0 \pm 106,0$ & $1032,5 \pm 130,81$ \\
4 & $1017.5 \pm 123,74$ & $1182,5 \pm 116,67$ & $1092,5 \pm 24,75$ & $1000,0 \pm 63,64$ \\
5 & $892.5 \pm 468,79$ & $973,0 \pm 525,92$ & $1227,5 \pm 536,03$ & $1112,5 \pm 535,46$ \\
\hline Rataan & $915,5 \pm 145,23$ & $1125,1 \pm 129,40$ & $1106,5 \pm 136,38$ & $923,61 \pm 403,11$ \\
\hline
\end{tabular}

Ket: R0 = Air minum saja, R1= Air minum+10\%kelor,R2= Air minum+20\%kelor,R3= Air minum +30\%kelor.
Bobot potong diperoleh dari hasil penimbangan ayam sebelum potong setelah sebelumnya dipuasakan dari pakan selama \pm 12 jam (air minum tetap diberikan). Rata-rata bobot potong ayam broiler pada penelitian ini berkisar antara $915,5 \pm 145,23-1125,1 \pm 129,40 \quad$ gram/ekor. Rataan bobot potong tertinggi pada perlakuan R1 dan terendah pada perlakuan R0. Bobot potong dipengaruhi oleh strain ayam, umur potong, ransum yang digunakan, jenis kelamin dan lain-lain. Hasil penelitian menunjukkan bahwa perlakuan R1 pada bobot potong memberikan hasil paling tinggi dibandingkan dengan R2, R3 sedangkan bobot terendah di dapatkan pada control dan secara statistik berpengaruh nyata. Faktor lain yang berpengaruh terhadap perbedaan nilai bobot potong tersebut salah satunya adalah suhu. Suhu yang baik untuk pertumbuhan ayam broiler adalah sebesar 19-27oC (Amrullah 2004). Kondisi yang cukup panas ayam broiler akan mengurangi konsumsi pakannya, sedangkan selama masa pemeliharaan berlangsung suhu lingkungan berkisar antara 26-31oC, namun pada penelitian ini konsumsi ransum tidak menurun hal ini berarti bahwa ayam yang dipelihara tidak mengalami cekaman panas yang berarti dengan demikian pembentukan daging pada masa penelitian berlangsung dengan baik. lebih besar dibandingkan dengan ayam yang hanya diberi air minum saja. Ini menunjukkan bahwa ekstrak daun kelor mempunyai kandungan yang mempengaruhi pertumbuhan ayam broiler.

\section{Bobot karkas}

Bobot karkas berkaitan erat dengan persentase karkas yaitu bobot potong yang besar sejalan dengan persentase karkas yang besar juga. Bobot karkas yang di hasilkan dipengaruhi oleh beberapa faktor yaitu umur, jenis kelamin, bobot potong, besar dan konformasi tubuh, perlemakan, kualitas dan kuantitas ransum serta strain yang dipelihara. Karkas adalah berat bersih potongan tubuh ayam utuh tanpa bulu, jeroan, kepala, dan kaki. Bobot potong yang besar akan menghasilkan bobot karkas yang besar pula. Perbedaan berat karkas dapat dilihat pda tabel 2.

Dari tabel dapat dilihat bahwa perlakuan sangat berpengaruh terhadap bobot karkas yang dihasilkan. Rata-rata bobot karkas ayam broiler pada penelitian ini berkisar antara $547,5 \pm 122,64-708 \pm 114,17$ gram/ekor. Rataan bobot karkas tertinggi pada perlakuan R2 dan terendah pada perlakuan R0 dan secara statistik berpengaruh nyata. Pada bobot potong perlakuan R1 memperoleh hasil terbesar sedangkan pada bobot karkas perlakuan R2 memperoleh hasil yang terbesar. Hal itu bisa diakibatkan oleh berat organ-organ selain karkas diantaranya adalah bulu, kepala,kaki atau jeroan ayam tersebut. Perlakuan pemberian air minum ditambahkan ekstrak daun kelor 
memperoleh hasil berbeda nyata $(\mathrm{P}<0,05)$. Hasil analisa dalam pemberian ekstrak daun kelor memberikan perbedaan nyata $(\mathrm{P}<0,05)$ pada bobot potong dan persentase karkas tetapi

Tabel 2 Rataan Bobot Karkas dan Bobot Relatif (\%) Ayam broiler umur 30 hari

\begin{tabular}{lllll}
\hline & R0 & R1 & R2 & R3 \\
\hline 1 & $532,5 \pm 67,17$ & $817,5 \pm 3,54$ & $735 \pm 77,78$ & $792,5 \pm 152,02$ \\
2 & $592,5 \pm 116,67$ & $687,5 \pm 60,10$ & $605 \pm 35,35$ & $652,5 \pm 67,17$ \\
3 & $497,5 \pm 3,54$ & $655 \pm 0,00$ & $725 \pm 63,64$ & $660 \pm 91,92$ \\
4 & $607,5 \pm 0,12374$ & $7955 \pm 141,42$ & $667,5 \pm 10,60$ & $640 \pm 91,92$ \\
5 & $507,5 \pm 286,38$ & $577,5 \pm 53,03$ & $807,5 \pm 243,95$ & $705 \pm 49,5$ \\
Rataan & $547,5 \pm 122,64$ & $706,5 \pm 108,55$ & $708 \pm 114,17$ & $690 \pm 93,12$ \\
\hline
\end{tabular}

Tabel 3: Hasil analisis keragaman persentase karkas dan giblet ayam broiler umur 30 hari

\begin{tabular}{llllll}
\hline Perlakuan & Potong & Hati & Karkas & Rampela & Jantung \\
\hline R0 & $916,5 \pm 82,87^{\mathrm{a}}$ & $0,034 \pm 0,005$ & $0,548 \pm 0,049^{\mathrm{a}}$ & $0,038 \pm 0,004$ & $0,006 \pm 0,002$ \\
R1 & $1125,1 \pm 88,43^{\mathrm{b}}$ & $0,039 \pm 0,007$ & $0,706 \pm 0,099^{\mathrm{b}}$ & $0,040 \pm 0,011$ & $0,007 \pm 0,002$ \\
R2 & $1106,5 \pm 90,39^{\mathrm{b}}$ & $0,038 \pm 0,002$ & $0,708 \pm 0,076^{\mathrm{b}}$ & $0,044 \pm 0,003$ & $0,006 \pm 0,001$ \\
R3 & $1085,0 \pm 111,01^{\mathrm{b}}$ & $0,042 \pm 0,008$ & $0,690 \pm 0,062^{\mathrm{b}}$ & $0,043 \pm 0,006$ & $0,006 \pm 0,001$ \\
\hline
\end{tabular}

Ket: R0 = Air minum saja, R1= Air minum $+10 \%$ kelor,R2= Air minum $+20 \%$ kelor,R3= Air minum $+30 \%$ kelor.

\section{Persentase Karkas}

Menurut Badan Standarisasi Nasional (2009) karkas diperoleh dari proses pemotongan ternak untuk menghasilkan tubuh unggas tanpa bulu, jeroan, kepala, leher, kaki, ginjal dan paru-paru. Berdasarkan hasil analisis ragam (Tabel 3) menunjukkan hasil berbeda nyata $(\mathrm{P}<0,05)$ terhadap persentase karkas dengan rataan yang diperoleh sebesar ?\%. Rataan persentase karkas tertinggi diperoleh pada perlakuan R1 yaitu ? dan terendah terdapat pada perlakuan R0 yaitu . Ayam broiler, kalkun dan unggas besar lainnya persentase pemotongan meningkat selama peningkatan umur, pertumbuhan serta kenaikan bobot tubuh ternak. Menurut Hayse dan Marion (1993) faktor yang mempengaruhi bobot dan persentase karkas adalah jenis kelamin, umur, aktivitas, bangsa, jumlah dan kualitas pakan, ditinjau dari perlemakan tubuh, berat potong dan konsumsi pakan. Hal yang dapat mempengaruhi persentase karkas adalah zat dalam pakan seperti nutrisi protein yang dikonsumsi ternak untuk menghasilkan daging. Sesuai dengan pendapat Andriana (1998) bahwa faktor yang mempengaruhi persentase tidak menunjukkan perbedaan nyata $(\mathrm{P}>0,05)$ terhadap presentase hati, rempela dan jantung seperti terlihat dalam tabel 3 . 
persentasi hati. Rataan persentase yang diperoleh pada penelitian ini lebih rendah dari hasil penelitian Arifin dan Widiastuti (2016) dimana burung puyuh yang diberi pakan komersial dengan suplementasi protein dan serat kasar tepung daun mengkudu memiliki persentase hati antara 2,52 - 2,65\%. Hasil penelitian ini sesuai dengan pendapat McLelland (1990) menyatakan bahwa faktorfaktor yang mempengaruhi ukuran, konsistensi dan warna hati yaitu bangsa, umur dan status individu ternak yang sama dan apabila keracunan warna hati berubah menjadi kuning, warna hati yang normal yaitu coklat kemerahan atau cokelat.

\section{Persentase Ampela}

Berdasarkan hasil analisis ragam (Tabel 3) menunjukkan penambahan larutan daun kelor memberikan pengaruh yang tidak nyata $(\mathrm{P}>0,05)$ terhadap persentase ampela. Hal ini disebabkan pakan perlakuan tidak mengandung serat kasar yang tinggi yaitu sebesar maksimal $4 \%$ untuk pakan periode starter dan $6 \%$ untuk pakan periode layer. Jumlah ini masih dibawah kebutuhan serat kasar maksimal 7\% berdasarkan Standar Nasional Indonesia sehingga persentase ampela antar perlakuan relatif sama. Hal ini sesuai dengan pendapat Frandson (1986) yang menyatakan bahwa ampela merupakan organ yang berfungsi sebagai penggiling pakan yang masuk dan prosesnya dibantu oleh grit, besarnya dipengaruhi oleh tinggi rendahnya serat kasar dalam pakan.

Persentase ampela yang diperoleh memiliki rataan $2,54 \pm 0,18 \%$ dengan persentase ampela tertinggi pada perlakuan R0 yaitu $2,63 \pm 0,14 \%$ dan persentase ampela terendah pada perlakuan R3 yaitu 2,48 $\pm 0,26 \%$. Persentase ampela yang diperoleh dari hasil penelitian ini lebih rendah dari hasil penelitian Asmawati (2015) dimana persentase ampela puyuh yang diperoleh memiliki rataan2,77 $\pm 0,49 \%$. Dharmawanti dan Ari (2012) menyatakan bahwa meningkatnya bobot ampela (gizzard) bukan disebabkan semakin meningkatnya pertumbuhan, melainkan karena fungsinya yang cukup berat dalam menggiling bahan makanan menjadi partikel yang lebih kecil juga untuk mengaduk bahan pakan tersebut dengan enzim pencernaan yang dihasilkan oleh proventiculus maupun empedu, sehingga pembesaran ampela ini sangat dipengaruhi oleh kandungan serat kasar bahan pakan. Jurnal Pertanian ISSN 2087-4928 Volume 4 Nomor 2, Oktober 2018113

\section{Persentase Jantung}

Berdasarkan hasil analisis ragam menunjukkan penambahan larutan daun kelor memberikan pengaruh yang tidak nyata $(\mathrm{P}>0,05)$ terhadap persentase jantung. Jantung adalah organ otot yang memegang peranan penting di dalam peredaran darah yang terbagi menjadi empat ruang yaitu dua bilik (bilik kanan dan bilik kiri) dan dua atrium (Ressang 1984). Rataan persentase jantung yang diperoleh sebesar $0,92 \pm 0,06 \%$. Hasil yang diperoleh antar perlakuan relatif sama karena sistem pemeliharaan yang sama (terkurung) dan aktivitasnya pun sama. Persentase jantung yang diperoleh dari hasil penelitian ini lebih tinggi dari hasil penelitian Pradikdo (2016) dimana persentase jantung puyuh yang diperoleh berkisar antara $0,73-0,80 \%$. Namun kedua penelitian ini sesuai dengan Fritzgerald (1999) bahwa bobot jantung puyuh berkisar antara 0,6$0,9 \%$ dari bobot tubuhnya. Ressang (1984) menjelaskan bahwa besar jantung tergantung dari jenis kelamin, umur, bobot hidup dan aktivitas hewan. Pembesaran ukuran jantung biasanya diakibatkan adanya penambahan jaringan otot jantung yang diakibatkan oleh aktivitas hewan tersebut.

\section{KESIMPULAN DAN IMPLIKASI}

\section{Kesimpulan}

Pemberian ekstrak daun kelor dapat digunakan untuk mengoptimalkan persentase karkas dan non karkas ayam broiler umur 35 hari.

\section{Implikasi}

Berdasarkan hasil penelitian dapat diberikan penambahan ekstrak daun kelor pada air minum sampai level $30 \%$ pada ayam broiler sampai masa panen umur 30 hari. 


\section{DAFTAR PUSTAKA}

Agustiana D, Endang T, Sujuti H. 2011. Serbuk Daun Kelor Menurunkan Derajat Perlemakan Hati dan Ekspresi Interleukin-6 Hati Tikus dengan Kurang Energi Protein. Jurnal Kedokteran Brawijaya 3: 125-130.

Astuti DA, Ekastuti DR, Firdaus. 2005. Manfaat Daun Kelor (Moringa oleifera) sebagai Pakan Ayam Pedaging. Prosiding Seminar Abubakar. 1992. Grading Karkas Broiler.Prosiding.Seminar Ikatan SarjanaPeternakan Indonesia ( ISPI ). Bogor. hal. 12 - 14.

Amrullah IK. 2004. Nutrisi Ayam Petelur. Cetakan 1.Satu Gunungbudi. Bogor.

Analisa L. 2007. Efek Penggunaan Tepung Daun Kelor (Moringa oleifera)dalam Pakan terhadap Berat Organ Dalam, Glukosa Darah dan Kolesterol Darah Ayam Pedaging. [Skripsi]. Fakultas Peternakan Universitas Brawijaya Malang.

Anggorodi HR. 1995. Nutrisi Aneka Ternak Unggas. Gramedia Pustaka Utama. Jakarta

Cwayita W. 2014. Effects of Feeding Moringa Oleifera Leaf Meal as an Additive on Growth Performance of Chicken, Physico- Chemical shelf-life Indikator, Fatty Acids Profiles and Lipid Oxidation of Broiler Meat.Master Thesis Fakulty of Science and Agriculture, University Fort Hare, Alice, South Africa.

Dhidhik HA, Widiastuti R. 2016. Persentase Karkas dan Giblet Burung Puyuh Pengaruh Suplementasi Protein dan Serat Kasar Tepung Daun Mengkudu dalam Pakan Komersial. Journal of Animal and Agronomy Panca Budi Volume 1 No:2.

Donovan P. 2007. Moringa Oleifera: The Miracle Tree. Www. Natural New.Com [20 juli 2017].

H.Fatrah, R.Handarini, E.Dihansih. 2018. Persentase Karkas dan Giblet Burung Puyuh (Coturnix-coturnix japonica) Jantan Umur 35 Hari Yang Diberi Larutan Daun Kelor.[Skripsi]. Jurusan Peternakan. Fakultas Pertanian. Universitas Djuanda. Bogor.

Hetland H, Svihus B, Choctt M. 2005. "Role of Insoluble Fiber on Gizzard Activity In Layers". Journal Applying Poultry. 14: 38-46.

Lusi L.R.H Dima. Fatimawali. Widya Astuti Lolo 2016. Uji Antibakteri ekstrak Daun Kelor (Moringa oleivera L) Terhadap Bakteri Escherichia Coli dan Staphylococcus aureus.

Luqman S, Suchita S, Ritesh K, Anil KM, Debabrata C. 2012. Experimental Assessment of Moringa oleifera Leaf and Fruit for Its Antistress, Antioxidant, and Scavenging Potential Using In Vitro and In Vivo. UIN Syarif Hidayatullah
Jakarta Assays. Hindawi Publishing Corporation Evidence-Based Complementary and Alternative Medicine : 1-12.

MoyoB,Oyedemi SPJ, Masika,Muchenje V. 2011. Polyphenolic Content and antioxidant Properties of Moringa oleifera leaf Meal Extracts and Enzymatic Activity of liver from goat pupplemented with Moringa oleifera /sunflower cake .meat Sci 02:29

Nuraeni.2016. Pengaruh Pemberian Tepung Daun Kelor (Moringa oleifera) dalam Ransum terhadap Karakteristik Karkas dan giblet Broiler. [Skripsi]. Universitas Hasanudin. Makasar.

OgbeAO, Affiku JP.2012. Effect of Polyherbal Aqueous Extract (Moringa oleifera, Arabic Gum,)and Wild Ganoderma lucidum) in Comparison with Antibiotic on Growth Performance and Haematological Parameters of Broiler Chicken, Res.J. Recent SSci, 1(7): 10-18.

Oludoyi IA, Toye AA. 2012. The Effect of Early Feeding Moringa oleifera Leaf Meal on Performance of Broiler and Pullet chicks. Agrosearch, 12(2):160-172.

Parwata.A.,P.Manuaba, S. Yasa and I.G.N.G. Bidura. 2016. Characteristics and Antioxidant activities of Gaharu (Gyrinops versteegii) leaves, J.Biol.chem. Research 33(1) : 294 - 301

Patrick L. 2006. Lead Toxicity Part II: The Role of Free Radical Damage and the Use of Antioxidants in the Pathology and Treatment of Lead Toxicity. Alternative Medicine Review 11(2): 114-127.

Prihayanti.2014. Potensi Tepung Daun Kelor (Moringa oleifera) sebagai Suplemen Beta Karoten untuk Menghasilkan Telur Puyuh yang Kaya Oksidan.Institut Pertanian Bogor. Bogor

Ressang, A.A. 1984. Patologi Khusus Veteriner. Edisi ke-2. NV. Percetakan, Bali.

ResnawatiH. 2004. Bobot potong karkas dan lemak abdomen ayam ras pedaging yang diberi ransum mengandung tepung cacing tanah (Lumbricus rubellus).Didalam, Prosiding Seminar Nasional Teknologi Peternakan dan Veteriner.Bogor, Pusat Penelitian dan Pengembangan Peternakan. Bogor.

SaputraHT, Khaira N,Dian S. 2015. Pengaruh penggunaan berbagai jenis litter terhadap bobot hidup, karkas, giblet, dan lemak abdominal broiler fase finisher di closed house. Jurnal Ilmiah Peternakan Terpadu. 3(1):38-44.

Sarjono HT. 2008. Efek Penggunaan Tepung Daun Kelor (Moringa oleifera Lam) dalam Pakan terhadap Persentase Karkas, Persentase Deposisi Daging Dada, Persentase Lemak Abdominal dan Kolesterol Daging Ayam Pedaging. Fakultas Bioteknologi. Universitas Atma Jaya Yogyakarta 
Septinova DT, Kurtini N, Purwaningsih, Riyanti. 2009. Pemanfaatan limbah udang terolah dalam ransum terhadap bobot hidup, karkas, giblet dan lemak abdominal broiler. Jurnal Ilmiah Peternakan Terpadu. 3(1): 85-91.

Setiadi D, Khaira N, Syahrio T. 2012. Perbandingan bobot hidup, karkas, giblet, dan lemak abdominal ayam jantan tipe medium dengan strain berbeda yang diberi ransum komersial broiler.[Skripsi]. Jurusan Peternakan. Fakultas Pertanian. Universitas Lampung. Lampung.

Sjofjan O. 2008. Efek Penggunaan Tepung Daun Kelor (Moringa oleifera) dalam Pakan terhadap Penampilan Produksi Ayam Pedaging [Skripsi]. Fakultas Peternakan Universitas Brawijaya. Malang.

Singh GP, Rakesh G, Sudeep B, Kumar S. 2012. Anti-inflammatory Evaluation of Leaf Extract of Moringa oleifera. Journal of Pharmaceutical and Scientific Innovation, 1(1); 22-24

Soeparno. 2009. Ilmu dan Teknologi Daging. Gadjah Mada University Press. Yogyakarta.

Sri Jumiati. 2017. Bobot potong, karkas, giblet dan lemak abdominal ayam broiler yang temulawak (Curcumaxanthorrhiza,Roxb) dalam pakan. Jitro vol.4 No.3

Suryanah1, H nur, dan Anggraeni. 2016. Pengaruh neraca kation anion ransum yang berbeda terhadap bobot karkas dan bobot giblet ayam broiler. Jurnal Peternakan Nusantara. Vol2 No. 1.

Sumarni. 2015. Pengaruh kuantitas ransum terhadap persentase karkas, giblet dan lemak abdominal ayam broiler. [Skripsi]. Fakultas Peternakan. Universitas Halu Oleo.Kendari.

SuyantoD, Achmanu, Muharlien. 2013. Penggunaan tepung kemangi (ocimum basilicum) dalam pakan terhadap bobot karkas, presentase organ dalam dan kolesterol daging pada ayam pedaging. [Skripsi]. Fakultas Peternakan Universitas Brawijaya. Malang.

WinedarH, ListyawatiS, Sutarno. 2004. Daya Cerna Protein Pakan Kandungan Protein Daging dan Pertambahan Berat Badan Ayam Broiler Setelah Pemberian Pakan yang difermentasi dengan Effective microorganism-4 (EM4). UNS. Surakarta 
